\title{
Creating a Literary Space to Debate the Mao Era:
}

The fictionalisation of the Great Leap Forward in Yan Lianke's Four Books

Sebastian Veg

\section{(2) OpenEdition \\ Journals}

Electronic version

URL: http://journals.openedition.org/chinaperspectives/6563

DOI: 10.4000/chinaperspectives.6563

ISSN: 1996-4617

Publisher

Centre d'étude français sur la Chine contemporaine

\section{Printed version}

Date of publication: 25 November 2014

Number of pages: 7-15

ISSN: 2070-3449

\section{Electronic reference}

Sebastian Veg, «Creating a Literary Space to Debate the Mao Era: », China Perspectives [Online], 2014/4 | 2014, Online since 01 January 2017, connection on 28 October 2019. URL : http:// journals.openedition.org/chinaperspectives/6563; DOI : 10.4000/chinaperspectives.6563 


\title{
Creating a Literary Space to
}

\section{Debate the Mao Era}

\author{
The fictionalisation of the Great Leap Forward in Yan Lianke's Four Books
}

\author{
SEBASTIAN VEG
}

\begin{abstract}
Since the scar literature of the early 1980s, fiction and fictionalised autobiography have played an important role in bringing to light the mass violence of the Cultural Revolution. However, these texts remained within a well-defined framework in which the political system itself was not questioned. Over the last decade, by contrast, the Chinese literary field has focused more specifically on the 1950s, with works such as Yang Xianhui's Chronicles of Jiabiangou (Tianjin, 2002), and Yang Jisheng’s Tombstone (Hong Kong, 2008). This paper focuses on Yan Lianke's Four Books (Hong Kong, 2010), a full-fledged fictionalisation in a fantastic mode of the famine of the Great Leap Forward in a village on the Yellow River. Considering literature in the context of theories of the public sphere, it suggests that Yan's book aims to broaden decisively the discussion on certain previously out-of-bounds aspects of the Mao era, an aim only partially thwarted by its failure to be published within mainland China. Four Books, like Yang Jisheng and Yang Xianhui's works, thus represents an attempt to call into question the original legitimacy of the PRC polity and to create debate within the Chinese-speaking public sphere on the foundations of the current regime.
\end{abstract}

KEYWORDS: Yan Lianke, Great Leap Forward, famine, memory, history, public sphere, literary space, censorship, fiction.

T he post-Mao era is usually considered to have begun with the elimination of the Gang of Four and Deng Xiaoping's consolidation of power at the Third Plenum of the $11^{\text {th }}$ Central Committee in December 1978, two years after Mao's death. However, the Chinese regime has never entirely called into question Mao's role and importance as the founding father of the nation. Most recently, the current secretary general of the CCP, $\mathrm{Xi}$ Jinping, has put forward a complex theory of "two irrefutables" (liangge buneng fouding 兩個不能否定), pointing out that the accomplishments of the Mao era could not be "refuted" by using the advances of the reform era. (1) In a recent essay, Joseph Fewsmith formulates the view that "[Mao's] legacy seems even more difficult to deal with today than it was 10 or 20 years ago." (2) The persistence of Mao's legacy has of course also been the subject of many scholarly studies: important ones include Geremie Barmé's In the Red, which points to the continued appeal of the figure of Mao in the cultural and intellectual field; Ching Kwan Lee and Guobin Yang's Re-envisioning the Chinese Revolution, which turns to grassroots social representations of the "revolutionary era"; and Sebastian Heilmann and Elizabeth Perry's Mao's Invisible Hand, in which the authors highlight the continuity in policy-making style between the Mao and post-Mao eras. ${ }^{(3)}$

The 1981 "Resolution on Certain Questions in the History of our Party" laid out the general framework in which official historiography or other public writing could tackle the Mao era, mainly in terms of "errors" along the road of building socialism. ${ }^{4}$ However, in parallel, the government enforced a politics of amnesia, by which public debate of the events of the pre-Reform era was actively discouraged in the public sphere. Fang Lizhi, confined to the US embassy in Beijing shortly after the repression of the 1989 democracy movement, wrote the famous essay "The Techniques of Amnesia of the Communist Party" (5) (Gongchandang de yiwang shu 共產黨的遺忘 術), in which he sets out his idea of duandai ("generational break"), accord-

A first version of this paper was presented at a conference held in the Maison française d'Oxford on 1-2 November 2013, within a collaborative project on "Literature and democracy" coordinated by Philippe Roussin and myself; thanks are due to Philippe Roussin and Anne Simonin for their invitation. A second version was presented in an AAS panel organised within the ANR-RGC project "New Approaches to the Mao Era," in the framework of which research for this paper was undertaken.

1. Xi began floating similar theories as early as 2011 , in a talk for the $90^{\text {th }}$ anniversary of the CCP. The classic formulation appeared in a January 2013 speech to the $18^{\text {th }}$ Central Committee; see: "Haobu dongyao jianchi he fazhan Zhongguo tese shehui zhuyi - zai shijian zhong buduan yousuo faxian yousuo chuangzao yousuo gianjin" (Unwaveringly uphold and develop socialism with Chinese characteristics - a practice of continuous discovery, creativity, and progress), People's Daily, 6 January 2013, http://politics.people.com.cn/n/2013/0106/c1024-20100407.html (accessed on 23 June 2014). This idea was reaffirmed in a long theoretical article authored by the Central Bureau of Party History and published in People's Daily on the eve of the Third Plenum: "Zhengque kandai gaige kaifang qianhou liangge lishi shiqi," People's Daily, 8 November 2013, http://politics.people .com.cn/n/2013/1108/c1001-23471419.html (accessed on 23 June 2014).

2. Joseph Fewsmith, "Mao's Shadow," China Leadership Monitor, No. 43, 14 March 2014, p. 1, www.hoover.org/research/maos-shadow (accessed on 23 June 2014). Following an article published by Li Yongfeng in Yazhou Zhoukan in 2013, Joseph Fewsmith suggests that Xi's reappraisal of Mao may have been inspired by an essay submitted by Zhu Jiamu of the Central Documents Research Office in 2007 prior to the $17^{\text {th }}$ Congress and rejected by Jiang Zemin.

3. Sebastian Heilmann and Elizabeth Perry (eds), Mao's Invisible Hand, Cambridge, Harvard University Asia Center, 2011; Geremie Barmé, In the Red, New York, Columbia University Press, 1999; Ching Kwan Lee and Guobin Yang (eds), Re-envisioning the Chinese Revolution: The politics and poetics of collective memory in reform China, Stanford, Stanford University Press, 2007.

4. For a general discussion of Mao's place in official historiography, see Arif Dirlik, "Mao Zedong in Contemporary Chinese Official Discourse and History," China Perspectives, No. 2012/2, 2012, pp. 17-28.

5. Fang Lizhi, "The Chinese Amnesia," The New York Review of Books, 27 September 1990, www.nybooks.com/articles/archives/1990/sep/27/the-chinese-amnesia/ (accessed on 16 November 2013). 
ing to which the CCP's hold on power is linked to its ability to cut off the memory of generation after generation of democratic movements, so that each generation must start from scratch, without knowledge of their predecessors' ideas and accomplishments.

This is not to say that no debate has taken place in China on the years from 1949 to 1978: whether behind closed doors in the upper echelons of the Party or in popular, "unofficial" (minjian 民間) publications, there has been, over the years, a fair amount of soul-searching about the events of Mao's reign. ${ }^{\left({ }^{6}\right)}$ As early as 1978, even before the Third Plenum consolidated Deng's power, a thaw in the literary and art world was signalled by the publication of two short stories, one of which (Lu Xinhua's "The Scar") gave its name to a whole literary movement commemorating certain episodes of the Cultural Revolution. From the late 1970s, literature thus played the role of a substitute for public discussion of the history of the Mao Era. A systematic, public, and officially sanctioned discussion in China of the history and politics of the Mao era, allowing both historians and citizens (and children educated in schools) to better understand the mechanisms of the political persecution campaigns that began in the early 1950s, of the Great Famine of the late 1950s and early 1960s, and of the mass violence that took place throughout the country during the Cultural Revolution has obviously remained elusive, although such a public discussion has often been highlighted as an indispensable prerequisite for true political reform and democratisation in China. However, writers and publishers have continually sought to use the loopholes of the publishing system, the perceived greater tolerance for fiction, and the generally liberal sympathies of publishers and journal editors to spark a public discussion on various episodes of the Mao era. Literature thus represents one of the areas in which Chinese society has tried to circumvent the limitations imposed by official discourse.

This paper obviously does not aim to provide a comprehensive overview of intellectual debates on the Mao era, or even to provide a full history of its literary treatment in China. It focuses more narrowly on one recent example of a fictional work that questions the previously well-defined borders of representing the Mao era in China. It is grounded in a theoretical framework that draws on Jürgen Habermas's definition of the public sphere and the role of literature in bringing about its historical institutionalisation, complemented by John Searle's definition of fiction as a pragmatic act. In Habermas's understanding, the modern public sphere appeared in Europe in the eighteenth century in conjunction with an educated, bourgeois society of readers. The bourgeois public sphere, enabled by the press and other publications, can be defined as "the forum... in which the private people - assembled as the public - gathered in order to constrain the public power to legitimate itself in front of public opinion." Habermas describes its advent as "the process during which the public, constituted of private individuals using reason, appropriates the public sphere controlled by authority, and establishes it as a sphere in which critique is directed at the power of the state, transforming a literary public sphere already endowed with a public and platforms of discussion." (7) Many discussions have been devoted to the normative dimension of Habermas's theory and its possible applications in China, a substantial review of which would go far beyond the scope of this paper. Undoubtedly, very strong constraints arise from writing inside what Perry Link has called the "socialist Chinese literary system." (8) Link considers that the "system" as such came to an end in the 1990s, but his recent publications continue to refer to the "system," highlighting that some of its practices survive. ${ }^{(9)}$ However, despite continued censorship and control, it is undeniable that the economic reforms of the 1990s have created new spaces for pub- lication and discussion, as Habermas set out in relation to eighteenth century Europe. This paper builds on the idea that literary works and their discussion by private people, through the print media and in the press, can lead to a critique of the power of the state or of its dominant narratives. In this sense, it understands China to be endowed with an embryonic public sphere that is in part a product of economic reforms, but also an emanation of a wider sinophone public sphere, building on the freedoms of press and publication that, although they are not realised in China, are guaranteed in Hong Kong, Taiwan, and on websites based outside the PRC. Four Books was ultimately not published in mainland China, but has been made widely available on the Internet including inside China (as discussed below): it can therefore be discussed in the framework of this wider sinophone public sphere.

Furthermore, this paper relies on Searle's understanding of fictional discourse as a pragmatic act endowed with intentionality (on the part of the author), communicational content, and a pragmatic effect on its readers, just like other types of discourse. Therefore, while fiction may be "playful," it is also understood as an intervention directed at a (potentially unlimited) group of addressees. ${ }^{(10)}$ This explains why, in addition to close textual reading of Yan Lianke's Four Books, this paper relies on two in-depth interviews with the author, through which the intentionality of the intervention can be better understood (though this should obviously not constitute a limit to possible readings and to its pragmatic effect). In parallel, public interviews are also quoted in which Yan makes similar points. ${ }^{(11)}$ Based on this approach, this essay makes the argument for a possible turning point in the way contemporary Chinese intellectuals are prepared to publicly discuss the Maoist period in PRC history.

6. Some recent examples of minjian voices would be the writings of Nanjing historian Gao Hua (1954-2012), whose study on Yan'an, Hong taiyang shi zenyang shengqi de (Hong Kong, CUHK Press, 2001), remains unpublished on the mainland; the review by economist Mao Yushi calling to "Bring Mao back to human stature" ("Ba Mao Zedong huanyuan cheng ren," Caixin, 26 April 2011), and lobbying by retired Party historian Xin Ziling to have Mao's name removed from Party documents in late 2011 and early 2012. Retired Peking University Professor Qian Liqun also recently published a massive two-volume biography of Mao in Taiwan: Qian Liqun, Mao Zedong shidai he hou Mao Zedong shidai (1949-2009). Ling yizhong lishi shuxie (The Mao era and the post-Mao era. An alternative historical narrative),Taipei, Lianjing, 2012.

7. See: Jürgen Habermas, Strukturwandel der Öffentlichkeit, Frankfurt, Suhrkamp, 1990 [1962], pp. 81 and 116 (my translations). Charles Taylor famously critiqued Habermas' definition of the public sphere in the name of a "politics of recognition" (a critique Habermas does not accept) grounded in a politics of difference that takes issue with the universalist politics of "equal dignity" inherent in Habermas's notion of the public. However, while the author is aware of this critique, this article does not construe Yan Lianke's questioning of the Mao era as an attempt to obtain recognition for a claim to an "authentic identity." See Taylor's and Habermas' contributions in Amy Gutman (ed), Multiculturalism: Examining the politics of recognition, Princeton, Princeton University Press, 1994

8. Perry Link, The Uses of Literature: Life in the socialist Chinese literary system, Princeton, Princeton University Press, 2000. Link's approach, although it does not explicitly quote Bourdieu, is grounded in an empirical understanding of literature as a "spectrum of viewpoints" (a Bourdieusian formulation Link uses on p. 56). Link defines this system as the combination of a bureaucracy borrowed from the USSR and an assumption of the relevance of literature widely shared in Chinese society. Its distinctive traits are the primacy of the relation between leaders and readers, to the detriment of writers, and its strong reliance on self-censorship, achieved through the "organised dependency" (Andrew Walder) of writers on the advantages offered by their work units.

9. For example, he writes: "Writers like Mo Yan are clear about the regime's strategy, and may not like it, but they accept compromises in how to put things. It is the price of writing inside the system. [...] Chinese writers today, whether 'inside the system' or not, all must choose how they will relate to their country's authoritarian government. This inevitably involves calculations, tradeoffs, and the playing of cards in various ways." Perry Link, "Does this Writer Deserve the Prize?", The New York Review of Books, 6 December 2012. Yan Lianke discusses this issue in his essay "Zai gaodu jiquan yu xiangdui kuansong de shuangchong tiankong xia" (Under the twofold heavens of a high degree of power concentration and relative tolerance), Yan Lianke, Chenmo yu chuanxi (Silence and Gasping), Taipei, INK, 2014, pp. 151-171.

10. John Searle, "The Logical Status of Fictional Discourse," New Literary History, Vol. 6, No. 2, 1975, pp. 319-332.

11. Yan Lianke's new collection of essays touching on censorship, amnesia, and other political issues (see note 9 above) was published as the present article went to press; it can therefore only be referenced rather than fully discussed here. 
The first section provides a brief historical overview, followed by an analysis of Yan's book and of its reception in China.

\section{The debate on the Mao era and the literary sphere: An historical overview}

Since the scar literature of the late 1970s, fiction and fictionalised autobiography have played an important role in bringing to light the personal traumas of the Cultural Revolution. Lu Xinhua's "The Scar" (Shanghen, 1978) (12) is about a young woman who breaks ties with her politically suspect family and goes to the countryside, only to find herself tainted by her family background. When her mother is eventually rehabilitated, she returns to Shanghai to look for her, only to discover she has just passed away. Texts like this one, often inspired by personal experience, nonetheless remained within a well-defined framework in which the political system itself was never questioned; on the contrary, people's belief in the Party and its ability to correct its own mistakes was often emphasised. This approach was largely mirrored in the 1981 Resolution that followed a few years later, in which the final verdict on Mao remained positive, despite the "mistakes" made by the collective leadership as early as the 1950s and the full-scale condemnation of the Cultural Revolution as "erroneous." (13) Following its earlier practice (a similar resolution had been adopted in 1951), the CCP was thus able to weave the "error" of the Cultural Revolution into a larger narrative of modernisation and historical legitimacy of CCP rule.

Intellectuals in the 1980s were, to an extent, prepared to play by these rules. Within the larger context of a political consensus on modernisation bringing together elites inside and outside of the Party, the pervasive understanding of the Mao era was formulated in culturalist terms acceptable to the CCP: under Mao, the benighted forces of Chinese peasant tradition, in the form of ignorance and autocracy, as expressed most egregiously in the personality cult of Mao, had reappeared. Mao had been weighed down by the ignorance and lack of education of the Chinese populace, both at the grassroots and among cadres. It was thus possible to denounce these forces in the name of Enlightenment, and to give the Party credit for endorsing a new push towards more Enlightenment. ${ }^{(14)}$ This narrative had the additional advantage that intellectuals could be portrayed as victims: under Mao, the Party-state had betrayed the intellectuals' trust by siding with the large masses of the benighted peasantry; the intellectuals, however, had remained loyal, and were now once again prepared to work together with the state and the Party to overcome these obscure forces. These were, by and large, the terms of the original debate on Mao in the 1980s, although dissenting voices existed. (15)

One of these voices belonged to Liu Xiaobo, who as early as 1986 wrote a famous essay entitled "Crisis!" in which he attacked intellectuals for only scratching the surface of the problems raised by the recent totalitarian past:

The rightist intellectuals in Zhang Xianliang's works not only do not lose their sense of respect for humanity and its value among the inhuman conditions of reeducation through labour camps, but on the contrary, thanks to the hard physical labour, by communing with ordinary people, and in the kisses and caresses of sincere, simple, hard-working village girls, they even find their way back to the Marxist-Leninist worldview and regain their affection for the proletariat, which purifies their souls and elevates their moral feelings. ${ }^{(16)}$
In Liu's view, despite Zhang Xianliang's unsparing descriptions of conditions in labour camps and of the humiliations undergone by intellectuals, his writing ignores the institutional dimensions of Maoist policy as well as the intellectuals' role in supporting it.

New forms of writing appeared in the 1990s, when Wang Xiaobo's novella "The Golden Age" (1993) marked a turning point. By trivialising the experiences of rusticated educated youths, which are portrayed as a series of sado-masochistic sexual humiliations perpetrated by the state, Wang Xiaobo was the first to question the victim status of intellectuals, whose masochism stood for their consenting enjoyment of their victim role. Through this ironic indictment of the victims, Wang no doubt sought a more active role for civil society in debating Maoism. ${ }^{(17)}$

Most recently, writers have opened up new perspectives, both in moving beyond the Cultural Revolution back to the 1950s, and in more explicitly questioning the role of the Party in episodes of mass violence and death. Three recent works stand out, only one of which was published in mainland China. Yang Xianhui's Chronicles of Jiabiangou (Tianjin, 2002) was perhaps the pioneering work in dealing with the Anti-rightist Movement and a deathly labour camp in Gansu during the great famine. Formally, it is presented as a collection of fictional stories, which allowed it to be published within the PRC, but it is largely based on survivor interviews. ${ }^{(18)}$ Yang Jisheng's Tombstone (Hong Kong, 2008) is a work of citizen history, but also an essay in its own right, in the same tradition of Chinese reportage literature, based on interviews and documents. Finally, Yan Lianke's Four Books (Hong Kong, 2010) is a fictionalisation of the famine of the Great Leap Forward in a labour camp on the banks of the Yellow River. Despite their formal differences, these works and their focus on the 1950s represent an attempt to call into question the original legitimacy of the PRC and to create a debate within the Chinese-speaking public sphere on the foundations of the current regime. ${ }^{(19)}$

12. See: Lu Xinhua et al., The Wounded: New Stories of the Cultural Revolution, trans. G. Barmé et al., Hong Kong, Joint Publishing, 1979.

13. See "Resolution on certain questions in the history of our party since the founding of the People's Republic of China," www.marxists.org/subject/china/documents/cpc/history/01.htm. For the Chinese original, see "Guanyu jianguo yilai dang de ruogan lishi wenti de jueyi," http://news.xinhuanet.com/ziliao/2002-03/04/content_2543544.htm (both accessed on 25 June 2014). The key assessment on Mao and the 1956-1966 decade is in paragraph 18: "In the course of this decade, there were serious faults and errors in the guidelines of the Party's work, which developed through twists and turns. [...] All the successes in these ten years were achieved under the collective leadership of the Central Committee of the Party headed by Comrade Mao Zedong. Likewise, responsibility for the errors committed in the work of this period rested with the same collective leadership. Although Comrade Mao Zedong must be held chiefly responsible, we cannot lay the blame for all those errors on him alone." Paragraph 20: "The history of the "cultural revolution" has proved that Comrade Mao Zedong's principle theses for initiating this revolution conformed neither to Marxism, Leninism nor to Chinese reality. They represent an entirely erroneous appraisal of the prevailing class relations and political situation in the Party and state."

14. See for example Jing Wang, High Culture Fever: Politics, aesthetics, and ideology in Deng's China, Berkeley, University of California Press, 1996, in particular chapter 2, "High Culture Fever:The Cultural Discussion in the Mid-1980s and the Politics of Methodologies," pp. 37-116.

15. See also Michael Berry's discussion of the dialectics of nostalgia and trauma in educated youth literature, focused on two more atypical authors (Wang Xiaobo and Ah Cheng), in Chapter 4 of $A$ History of Pain, New York, Columbia University Press, 2008, especially p. 260.

16. Liu Xiaobo, "Weiji! Xin shiqi wenxue mianlin de weiji," Shenzhen Qingnianbao, 3 October 1986. See also my French translation in Liu Xiaobo, La Philosophie du porc et autres essais, Paris, Gallimard, "Bleu de Chine," 2011, pp. 57-87.

17. See: Sebastian Veg, "Utopian Fiction and Critical Reflection," China Perspectives, No. 2007/4, pp. 75-87.

18. See: Sebastian Veg, "Testimony, History and Ethics: From the Memory of Jiabiangou Prison Camp to a Reappraisal of the Anti-Rightist Movement in Present-Day China," The China Quarterly, Vol. 218, June 2014, pp. 514-539.

19. There were a few isolated attempts to discuss the famine in literary works in the 1980s: Perry Link mentions the anonymous play Wildfire and novellas by Zhang Yigong, "The Story of Criminal Li Tongzhong" and Qian Yuxiang, "History, be my judge!". See Perry Link, The Uses of Literature, pp. 254-255. 
In a first attempt to highlight how these works differ from past treatments of the Mao era, the following characteristics can be proposed as a working framework, which this essay will return to in detail below:

(1) Breaking with the "safer" period of the Cultural Revolution, which was singled out as "completely erroneous" in the 1981 Resolution and carefully circumscribed as a parenthesis in PRC history, these works go back to the politically more "complex" foundational period of the 1950s.

(2) Rather than revealing an "accident" in its development, these works question the nature of the PRC regime.

(3) Rather than portraying intellectuals as victims, they attempt to address their "guilt" or at least complicity in the establishment and development of the regime.

(4) Rather than focusing on the sufferings of the elite, they attempt to document the experience of ordinary people as victims of the regime and to endow them with agency.

(5) While many previous publications focused on individual testimonies, making no claim as to the overarching political structures, these works attempt to go beyond purely individual narratives and to open a public debate on history.

Yan Lianke's singular novel raises specific questions about the sort of public sphere for critique of official narratives that literature can attempt to open up, within certain limits, as highlighted by its non-publication in mainland China. It has, however, been made available and widely discussed on the Chinese Internet. Read together with Yan Lianke's outspoken essay on amnesia published in the international media, it deals with the writer's responsibility to commemorate the past and fight forgetting. More practically, it raises the problem of the relationship between intentionality, as implicit in Searle's pragmatics, and literary form, which opens up a multitude of meanings for the reader. How can the responsibility to remember and the intention to commemorate be translated into an open literary form, without the risk of being reduced to silence by the institutions of literary censorship in China? Perry Link, among others, has highlighted the risks inherent in engaging in the strategies of avoidance that are necessary to enter the Chinese public sphere. ${ }^{(20)}$ Furthermore, how can a fictional narrative re-establish forgotten historical events? Finally, if what is most lacking today is an open debate within the public sphere about the mass violence of the Mao era, how can a work of fiction spark a historical debate, and leave the necessary space for polysemy and discussion?

\section{Yan Lianke's Four Books}

Yan Lianke's Four Books, first published in 2010 in Hong Kong, marks a new turn in the way Chinese literature has framed the historical events of the Mao era, attempting to engage with the massive loss of life during the Great Leap Forward, and to offer reflections on how individuals, some of them highly educated, contributed to creating the climate of political terror in which the famine took place. When discussing the motivations for writing a book about the great famine of 1958-1961, Yan underlines that most writers after 1978 had limited themselves to writing about the Cultural Revolution: while this may have been natural for writers of his generation (he was born in 1958) who had experienced it, he criticises the generation of his parents who had lived through the Great Leap Forward and the famine but failed to write about it. Perhaps, he hypothesises, be- cause in 1978 they were fully occupied reflecting on the Cultural Revolution, and because state politics were more restrictive regarding the "myth of the 1950s," the famine was never explicitly approved as an object of criticism in the same way as the Cultural Revolution in the 1981 resolution. (21) Liu Xiaobo in "Crisis!" had already mentioned that many writers did not dare to pursue their critique beyond the Cultural Revolution, because this would mean questioning the very foundations of the People's Republic that were laid down in the 1950s. For Yan, writings on the Cultural Revolution in the 1980s were both too uniform (dandiao) and too fragmented: everyone wrote about their own memories rather than reflecting on the underlying political system. (22) There was no literary reflection of the variety of experiences: while $90 \%$ of the population has no ability to speak out, those who could spoke out only about themselves. The CCP had invented the practice of suku or "airing grievances," by which peasants could complain in public about their cruel treatment at the hands of landlords: for him much of the Cultural Revolution literature followed the suku model, in which intellectuals are only innocent victims. He therefore set out to write a book which was both more polyphonic and could question the role played by intellectuals. ${ }^{(23)}$

\section{Memory and amnesia}

Against state-sponsored amnesia, Yan believes that the writer's foremost duty is to write a well-constructed literary work, as only literary value can ensure the rebuilding of memory, as shown by the great Chinese novels that have survived to document bygone eras. ${ }^{(24)}$ In April 2013, he published an op-ed in The New York Times entitled "On China's State-sponsored Amnesia" in which he denounced a state policy in which "Lies are surpassing the truth. Fabrications have become the logical link to fill historical gaps." To him, writers working within the system are somehow complicit:"The state is not the only player to be blamed for the nation's amnesia in today's China. We must also look at Chinese intellectuals, as we appear to be content with this forced amnesia." He contrasts Chinese writers with Russian writers such as Bulgakov and Pasternak whose works "did not [simply] rebel against state power; they are more about preserving and restoring a nation's memories." In China, on the contrary, writers are eager to espouse the narrative sponsored by the state: "Naturally, we thus replace the forgotten past with fiction and build splendid lies over reality. And we do this without feeling any sense of moral guilt - it's all in the name of artistic creativity." (25)

20. Perry Link refers to a "reverse magnet syndrome" that involves approaching problems like the Great Famine and then deflecting attention from their contentious aspects by using techniques such as "daft hilarity" (in the case of Mo Yan). Although the "socialist system of literature" as such is defunct, its technique of control relying on "organised dependency" continues to ensure that most writers will continue to make the "correct" choices of subject-matter "in order to preserve [their] career prospects under Party rule." See Perry Link, "Politics and the Chinese language," ChinaFile, 24 December 2012, http://chinafile.com/politics-and-chinese-language (accessed on 12 August 2014).

21. Interview with Yan Lianke, Hong Kong, 11 October 2013.

22. Ibid.

23. Interview with Yan Lianke, Hong Kong, 24 May 2012. On the suku model, see: Feiyu Sun, Social Suffering and Political Confession: Suku in Modern China, Singapore, World Scientific, 2013. See also Yan Lianke "Kongque yu beipan jiang yu wo zhongsheng tongxing" (Fear and rebellion will accompany me all my life), Chenmo yu chuanxi, op. cit., pp. 127-150.

24. Interview with Yan 2013.

25. Yan Lianke, "On China's State-sponsored Amnesia," The New York Times, 1 April 2013, http://www.nytimes.com/2013/04/02/opinion/on-chinas-state-sponsored-amnesia.html?_r=0 (accessed on 25 June 2014). The Chinese version was first published in Yan's new collection under the title "Cuojia shiji yu wenxue jiyi" (State amnesia and the memory of literature), Chenmo yu chuanxi, op. cit., pp. 9-23. 
While Yang Jisheng helps us to understand the facts (zhenshi de shiqing), Yan believes that his own writing can bring back the reality of feelings and memories (zhenshi de ganqing). Accordingly, although the idea for the novel was inspired by the discovery of historical traces (around 1989-90 when an army colleague in Lanzhou told Yan about finding bones in the desert that had belonged to Rightists who died in a labour camp), he felt no need to undertake any historical research. ${ }^{(26)}$ In the op-ed as well as the interview, Yan therefore presents his novel as the outcome of a deliberate strategy to counter duandai as defined by Fang Lizhi. Although some critics may find his pronouncements disingenuous and designed to curry favour with overseas readers, (27) in the final analysis, the "impurity" of authors' motivations is a defining fact of literature; it may therefore be more productive to study how these pronouncements tally with the design of the novel and the social effects of its reception. Relying on an international public sphere, in the age of the Internet, may also be a strategy to transform the domestic one.

The structure of the novel stands out by its complexity. In this respect, as well as its subject matter, it reveals some continuities with Yan's earlier work, Pleasure (Shouhuo, 2004, published in English as Lenin's Kisses), which is made up of a main narration and footnotes presented as "padding" (xuyan 絮言) which, as highlighted by Liu Jianmei, are designed to document the past, as "Forgetting is our common sin." (28) Another similarity that confirms Yan's long-time preoccupation with the Mao era is the image of the commercial exploitation of a Lenin Memorial Hall in Pleasure, a metaphor for the Mao mausoleum in Tiananmen Square.

Four Books is divided into four narratives (in fact, each of these "books" is broken up into short extracts and presented in collage form, not continuously), each of which is linked with another, canonical, text. Events take place in a labour farm on the Yellow River (Zone 99, which may refer to "eternity" in Chinese), where about 100 intellectuals are made to work, first to temper steel, then to grow astronomical outputs of wheat, under the direction of the "Child," the camp leader. Individuals are named after a personal characteristic (Writer, Laboratory, Music, Religion). The novel alternates between three narratives; the fourth "book" appears in a single chunk as an epilogue ("The New Myth of Sisyphus," rewriting a Greek myth). Two of the narratives are ostensibly written by one of the characters of the narrative, known as the "Writer": one to denounce other inmates to the authorities ("Account of Criminals"), the other a "novel" entitled "The Old Bed" (referring to the old riverbed of the Yellow River). The third one, "The Child of Heaven" is a third-person heterodiegetic (29) narration centred on the character of the Child with strong biblical allusions and vocabulary. The complexity of the structure therefore calls for some decoding and contextualisation of each of the narratives before any further interpretations are made.

\section{Maoism as religion ("The Child of Heaven")}

The use of religious vocabulary and biblical narration in "The Child of Heaven" is one of the most striking features of the novel. On the first page of the book, the establishment of the camp is recounted as a second Genesis with the rhythmical repetition of the phrase "and it was so": "And it was so. God separated light from darkness. Light was called Day and Darkness was called Night. There was evening and morning" (p. 30). (30) The Child returns to the great plain, proclaiming: "I have returned. From above, from the county-town. I will lay down ten commandments" (p. 31). By comparing the child to Moses, and the local bureaucrats to heavenly intercessors ("from above"), the author makes the comparison between the Mao-state and religion immediately explicit. It is of course an ironic one, as becomes even more apparent when the Child informs the men that they must produce 500 pounds of grain per mu of land to catch up with the US and surpass the UK, repeatedly threatening to kill himself if the men don't carry out his orders. ${ }^{(31)}$

Throughout the novel, Yan Lianke develops a parallel between this biblical narrative and Maoist politics, a cult based on red flowers and stars, which the inmates can earn for their good deeds. The Child displays the naïve but unquestioning belief in revolution of the Red Guards, hinting at the transformation of an entire nation of adults into brainwashed children. The comparison is reinforced by the thematic use of a character called simply Religion. A Christian, he is persuaded by the Child to trample on and destroy his Bible and prints of the Virgin Mary. On one occasion, Religion is informed on by the Writer and is discovered to have hidden a miniature bible inside Marx's Capital, a work the Scholar had helped translate (p. 138). But the Child also shows some interest in the Bible: on one occasion, he asks Religion to tell him a story "from the Book you like most" (p. 178); on another the inmates find him reading an album of Stories from the Bible and, when Religion begins to deface his last print of the Virgin Mary to obtain food from him, the Child stops him (p. 289). More generally, the world of the labour camp rests upon acts of faith: the possibility of working miracles by producing hitherto unheard-of quantities of grain per $m u$, or by making steel out of the silt of the Yellow River. Interestingly, Yan's interest in the ritual aspects of Maoist politics is in fact quite similar to what sociologists have described as the "ritualisation of processes of production," whereby the aim is no longer to produce but to "remould" peasants' representations. ${ }^{(32)}$ Yan is no doubt also drawing on Mao's status as a worker of miracles in the countryside. ${ }^{(33)}$

The Child is a particularly puzzling character. Just as there is no explanation of the establishment of the camp, there is no given source for the narrative of "The Child of Heaven" - like the biblical narrative, it is omniscient and without an identifiable narrator. Yan underlines that the Child, similarly, has no biographical background and no psychological plausibility. He is what Tsai Chien-hsin and Yan Lianke have termed "a little young Fascist," who whole-heartedly believes in the system and is prepared to sacrifice himself

26. Interview with Yan 2012.

27. Four Books has to date been translated into French by Sylvie Gentil (Les Quatre Livres, Arles, Picquier, 2012), but its publication seems to have received less international media coverage than Serve the People or Mo Yan's recent works. It has also been translated into Czech as Čtyři knihy by Zuzana Li, which may have played a role in the awarding of the Kafka Prize to Yan in 2014 (I would like to thank an anonymous reviewer for pointing out this connection).

28. This sentence appears on the cover of Pleasure. See Liu Jianmei, "To Join the Commune or Withdraw from it. A Reading of Yan Lianke's Shouhuo," Modern Chinese Literature and Culture, Vol. 19, No. 2, 2007, pp. 1-33, p. 25.

29. Heterodiegetic narration (as defined by Gérard Genette) refers to a configuration in which the narrative voice cannot be identified as belonging to one of the characters in the narrative. This characteristic sets "The Child of Heaven" apart from the two other "Books" mentioned above in which the narrator is the character named Writer.

30. Page numbers refer to Yan Lianke, Sishu, Taipei, Maitian, 2011. See also chap. 7:4 - Entitled "Exodus," this chapter tells the "miracle" of making steel from the sands of the Yellow River.

31. Yan has previously used biblical allusions in the first chapter of The Dreams of Ding Village, where three of Joseph's dreams from the book of Genesis appear in the form of a prophecy. However, this is the first time he draws an explicit parallel with Maoism.

32. Guo Yuhua, "Folk Society and Ritual State," in Laurence Roulleau-Berger and Li Peilin (eds), European and Chinese Sociologies: A New Dialogue, Leiden, Brill, 2011, p. 220.

33. In an interview, Yan Lianke explicitly discusses the transformation of Mao into a saint in the countryside, commenting that people are controlled by gods (shen dui ren de guanli); in his view, Mao could be seen as a god: people have doubts, but venerate him because he holds power. Interview with Yan 2012. 
to it. (34) However, at the end of the novel, after travelling to Beijing, the Child also changes. He goes to Beijing with 18 gigantic ears of wheat, grown with the blood of the Writer, because he hopes to earn a special mention for his Zone; by this time half of the inmates have died, and the Scholar entrusts him with a manuscript that is to reveal the truth of the situation to the central authorities. Although at this time, the inmates have already received the visit of a central leader whose physical description suggests a resemblance with Liu Shaoqi, and who has understood the extent of the famine, they still believe that the centre can help them. However, when the child returns, there is no account of his stay in Beijing; rather, he distributes red stars "made of steel" (p. 365), which will allow all inmates to return home, and the next evening he crucifies himself on a makeshift cross. Has he lost his childish faith in the system? Has his interest in the Bible led him to a kind of conversion that inspires his self-crucifixion? Tsai Chien-hsin, in his preface to the Taiwanese edition of the book translated on the MCLC website, discusses the ambiguity of the character of the child who ultimately turns himself into a martyr to atone for his previous wrongdoings. As Tsai writes, his self-crucifixion "may well be a plea for absolution as well as a martyrdom motivated by true, altruist socialist ideals." (35) Most interestingly perhaps, with the biblical simplicity of his Mao-like pronouncements, he raises the question for the reader of whether, and how, the Party can repent and atone for its sins.

An interesting point of detail in this regard is the narration in "The Child of Heaven" of how the great famine begins. In Chapter 13, the third section begins with the following sentences: "This rain lasted for forty days, and boundless water covered the world. Noah insisted on making an Ark, and was thus able to succour the remaining men and animals" (p. 268). While this narration seems to accredit the official narrative of a famine provoked by a natural catastrophe that cannot be mastered, we should note that no similar narration appears in the other chronicle of events. Perhaps the author is precisely suggesting that within the logic of Maoist faith the failure to fulfil the quotas of grain could only stem from a heavenly curse of biblical dimensions.

\section{The intellectuals' guilt ("The Old Course")}

In another dramatic break with most previous writing about the Mao era, the author has structured Four Books as an indictment of intellectuals, who make up the mass of the inmates of the labour camp. Their guilt is twofold: they are accused of being among the perpetrators during the Mao era, but also of failing to face up to their own past in transmitting the memory of the events. This idea is strongly conveyed in the two other narratives that make up the bulk of Four Books, both of which are ostensibly written by a character known as the Writer. He is something of a celebrity, whose works have been extolled by the system before the campaign targeting intellectuals, in which he is designated for rustication by popular vote inside his work unit. However, the authorities take pity on him and agree to give him preferential treatment if he agrees to watch over the other inmates and deliver weekly written reports to the Child. While all the intellectuals in Zone 99 spend a large part of their time informing on others (in particular on possible illicit relationships) in the hope that they can earn enough red flowers to go home, the Writer surpasses all others in his systematic betrayal of all other inmates. He informs on the Scholar and Music, revealing their "crime of adultery" (tongjian fan 通姦犯) to the authorities; at the same time he also double-crosses Laboratory (who is trying to catch them red- handed) in order to single-handedly pocket the benefits of his snitching. He again denounces those who have lied about the number of red stars after the Child's tent burns in Chapter 11, and spies on Music even during the deadly famine in Chapter 14. He is also always ready to participate in mass campaigns, and uses the last drop of his own blood to grow oversized ears of wheat. While all intellectuals are also victims, the writer in particular is singled out as a perpetrator and avid collaborator in both the authorities' irrational production plans and ubiquitous surveillance.

However, the Writer ends up dissatisfied with "Record of Criminals," the reports in which he informs on others, and while he is growing wheat far from the camp, he turns to writing a fictional narrative as a complement (p. 234). It is only in this narrative that the records of famine and cannibalism appear. Because of the pervasive famine, inmates are eating the dead bodies of other inmates in Zone 99: this is in keeping with the use of cannibalism as a trope in Chinese literature throughout the twentieth century to signify the debasement of the most basic ethics of humanity. ${ }^{(36)} \mathrm{How}-$ ever, Yan Lianke ends up reversing this trope. The Writer, having informed on Music and her "adultery" with the Scholar, as well as with a well-connected official from a neighbouring zone, who gives her food and whom the Writer tries to blackmail, is alerted by the official that Music has died of overeating during a tryst with him. He then finds his own reports to the Child informing on her among her belongings. At this point, to request forgiveness both from her corpse and from her lover the Scholar, the Writer cuts off two chunks of his own flesh from his calves and boils them. One is to be buried with Music, the other is served up to the starving scholar as pork meat. When the writer places the second piece together with his reports on Music's dead body, the Scholar understands what he has eaten and exclaims: "Dushu ren ya... Dushu ren..." (Ah, educated people... educated people..., p. 341). The trope of cannibalism is thus inverted: it becomes a means of repentance (chanhui 懺悔) for the intellectual, who is finally able to confront his own complicity in the system and understand his own role as a "cannibal." Although the term chanhui does not appear in the novel, Yan has used it in several public statements: its religious connotations (mainly but not only Christian) suggest that, for Yan also, the main task in confronting the legacy of the Mao era is of a moral nature. ${ }^{(37)}$

34. See Tsai Chien-hsin, "The Museum of Innocence: The Great Leap Forward and Famine, Yan Lianke, and Four Books," MCLC, 2011, p. 6. Yan Lianke has also used this expression, although obviously not in the novel. In an interview, he refers to him as a "young Fascist" (xiao Faxisi) whom thousands of intellectuals happily obey in the labor camp. See: "Yan Lianke: Shenghuo de xiabian haiyou kanbujian de shenghuo" (Yan Lianke: Below life there is another invisible life), Nanfang Zhoumo, 27 May 2011, www.infzm.com/content/59605 (accessed on 12 August 2014).

35. See Tsai Chien-hsin, "The Museum of Innocence," p. 7. Also noting that Four Books is the first fullfledged fictional inquiry into the Great Famine, Tsai reads it primarily as a moral inquiry, in conjunction with David Grossman's holocaust novel See Under: Love and Lu Xun's two prose poems "Revenge" I and II in Wild Grass. Just like the Christ-figure in "Revenge," Tsai reads the character of the Child as a probing of moral ambiguity, whose self-crucifixion reveals a mix of "sadistic autoeroticism and a disgraceful renunciation" (p. 7). By connecting it with Lu Xun's understanding of fiction as pharmakon, Tsai seems to suggest that the crucifixion of the Child can lead to a symbolic expulsion of the "poisonous" Maoist past from the city.

36. See the comprehensive overview in Gang Yue, The Mouth that Begs: Hunger, cannibalism, and the politics of eating in modern China, Durham, Duke University Press, 1999; and the enlightening critique in Katherine Edgerton-Tarpley, "Eating Culture: Cannibalism and the Semiotics of Starvation, 1870-2001," in Tears from Iron: Cultural Responses to Famine in Nineteenth-Century China, Berkeley, University of California Press, 2008, pp. 211-233.

37. For example: "In Four Books, one intellectual deeply repents [chanhui], and that is the Writer, who is also an informant. His repentance is more or less unprecedented among contemporary Chinese intellectuals." In "Yan Lianke: Shenghuo de xiabian haiyou kanbujian de shenghuo," art. cit. This is not entirely unprecedented: the first intellectual to call for "repentance" was Liu Zaifu in his 1986 essay "Wenxue yu chanhui yishi" (Literature and the conscience of repentance), the publication of which was blocked by Bo Yibo until 1988. See Perry Link, The Uses of Literature, op. cit., p. 45, note 109 . 
In an interview, Yan Lianke highlights that while intellectuals in China have always been very good at criticising others, in this book they repent and criticise themselves: "Since Yan'an, all intellectuals have been both victims and guilty. How was it that intellectuals became the greatest collaborators of the regime? Worse than that: what they have told us are lies. Much worse than fake milk powder is the fake history they have produced. At least with milk powder, you can buy the real thing in Hong Kong. But our history textbooks have made a whole nation amnesic." (38) The Writer's repentance in the novel, as expressed in the act of cannibalism, therefore also leads to a reassessment of how to write about the events of the famine and to publish the novel that he began scribbling "in the blanks between the 'Reports on criminals' that I wrote for the Child" (p. 212): "I want to write a really good book, not for the Child, not for the country, nor for this nation and its readers, only for myself" (p. 211). This purely individual account, although a novel and thus not factual, may turn out to be the most truthful account of the famine. Beyond his moral critique, Yan therefore uses the two accounts by the Writer to convey a narrative of history different from the official one and to illustrate the gap between the two.

\section{The reception of Four Books: Opening a debate on history}

It might seem paradoxical to initiate a discussion on the public sphere starting from a book that was not published in mainland China. However, contrary to what Tsai Chien-hsin writes, ${ }^{(39)}$ Yan did not pre-emptively selfban the novel by not submitting it to mainland publishers: rather it was submitted to several commercial publishers in succession, who turned it down, so that in the end it had to be published in Hong Kong. According to Yan, this was due to lack of precaution on his part: if the first refusal had been kept secret, other publishers might have considered the book seriously (as happened with his new book, just published, Zhalie zhi or Chronicle of Zhalie/Blow-up); as it was, news leaked out that no one would touch it, a self-fulfilling prophecy. Yan therefore points out that fiction is not necessarily easier to publish than documentary research; depending on whether the author is deemed "trustworthy," different standards may also apply. ${ }^{(40)}$ Whatever the case may be, Yan did try to make the novel available to the mainland readership, even making certain changes to maximise its publication chances so that "readers with the same mother tongue, history, and culture, living on the same piece of earth, could access a not too poor version of the book." (41)

Yan develops several strategies that can be understood as targeted at sparking debate among mainland readers. And indeed, such a debate has taken place, to some extent, with the publication of newspaper reports and scholarly articles on the book by famous critics and academics such as Sun Yu (dean of Literature at People's University), Chen Xiaoming (Peking University), and Wang Binbin (Nanjing University), as well as other academics. ${ }^{(42)}$ These articles appeared in the Chinese media at the same time as and in the context of other reports on the great famine, such as the investigative special feature of Nanfang Renwu Zhoukan titled "Da jihuang" (the Great Famine) in May 2012. ${ }^{(43)}$ The present section is therefore devoted to connecting the author's narrative strategies with the reality of the readings that took place in China. In particular, the polyphonic technique, as exemplified in the last "book" (Sisyphus), opens the possibility of multiple readings and debates about history. The fact that such debates took place, albeit in literary journals or on more obscure websites, highlights how the existence of a relatively autonomous sphere for the discussion of literature, as it emerged from the Chinese market reforms of the 1990s - in a way not unlike the "literary public sphere already endowed with a public" described by Habermas - can indeed open up a wider social space of political discussion.

\section{Reception in China}

Although Four Books was not published in China, it has a distinct reception history on the mainland. Beijing Youth Daily reported as early as 28 February 2011 that the People's University Faculty of Literature, where Yan Lianke holds a position as professor, organised a conference on Four Books and on an essay collection by Yan titled Discovering Fiction (Faxian Xiaoshuo) published simultaneously by People's University, on 26 February 2011. The article quotes the author as well as comments by the dean, Sun Yu, and writer Zhang Yueran, and mentions that the book has been printed and a small number of copies presented to friends. ${ }^{(44)}$ Around the same time, the first full reviews began appearing in Hong Kong and Singapore media and circulating on the Internet. In June, Southern Metropolis Daily printed a full-page article by an occasional contributor named Zhao Yong, ostensibly devoted to the essay collection, but which describes in passing how he read a self-printed edition of the novel, which many friends around him were pressing him to finish and pass on to them. ${ }^{(45)}$ Post-80s writer Jiang Fangzhou mentions Yan Lianke's "publicity lecture tour" about this novel in another article published in Shenzhen under the telling title "Remedying political naiveté by reading books." (46) Liberal professor Wang Binbin, who also received a private copy as a gift, provides a full-fledged description of the plum-coloured cover inscribed with the words si shu in Lu Xun's calligraphy and the author's afterword "The writer as rebel" (Xiezuo de pantu 寫作的叛徒). (47) Finally, the nomination and shortlisting of Four Books for the fourth Hongloumeng prize of sinophone literature in July 2012 (awarded to Wang Anyi's Tian xiang 天香 - Heavenly scent) unleashed a new wave of reporting in the mainland press.

Wang Binbin, writing in the April 2011 issue of Fiction Review (Xiaoshuo pinglun), introduces Four Books at length, and, after outlining its literary qualities, dwells particularly on its depiction of dehumanisation and moral breakdown, as well as the act of self-redemption (jiushu 救贖) by the writer who cuts off his flesh. He concludes with the "repentance" (chanhui) of the Child, expressed in his self-crucifixion, and regrets that Yan does not use a

38. Interview with Yan 2013

39. Tsai Chien-hsin, "The Museum of Innocence," art cit., p. 4. This re-assessment is based on Yan's own assertion (interview 2013 and afterword to the privately printed edition), but is backed up by names of the many publishers he claims to have submitted the novel to and details of the process.

40. Interview with Yan 2013. Yan jokes that if he had written Frogs on birth control, it would have been turned down, while under Mo Yan's signature it was awarded the Mao Dun prize.

41. Yan Lianke, "Xiezuo de pantu (Sishu houji)" (The writer as rebel: Afterword to Four Books), 16 October 2010, word document provided by the author.

42. See also presentations by Wang Yao (Suzhou University) and Chen Guangwei (People's University) at the conference on Yan Lianke and Yu Hua held at HKUST on 10 October 2013.

43. See Nanfang Renwu Zhoukan, No. 299, 21 May 2012, special feature pp. 34-51.

44. "Yan Lianke: Wo yao nuli zuo yige xiezuo de huangdi, er fei bimo de nuli" (Yan Lianke: I want to work hard on being a king of writing, not a slave of the pen), Beijing Youth Daily, 28 February 2011.

45. Zhao Yong, "Yan Lianke de zixing yishi" (Yan Lianke's self-reflexive consciousness), Southern Metropolis Daily, 26 June 2011

46. "Tongguo kan shu lai yuanjie zhengzhi youzhibing," Southern Metropolis Daily, 16 July 2011.

47. Wang Binbin, "Yan Lianke de Sishu" (Yan Lianke's Four Books), Xiaoshuo Pinglun (Fiction Review), Vol. 2011/2, 2011, pp. 18-22. 
more "mundane" (shisu 世俗) mode of redemption: "If he had died under the gun barrels of dictatorship, leading the inmates out of the concentration camp and attacking the control checkpoint, I would have been even more moved." (48) He nonetheless endorses the book and its critique of history.

Chen Xiaoming's article is similar in tone, though more scholarly in composition. Writing in Review of Contemporary Writers (Dangdai zuojia pinglun) in late 2013, he focuses on what he terms "scenes of shock" (zhenjing changjing 震驚場景) in three of Yan's novels; the one in Four Books being the death of Music. He also discusses the Writer as a hero who, by cutting off his own flesh, becomes a fighter against "modernity" (a euphemism often used by left-leaning critics for the political regime). More prone than Wang to using theoretical references, he ends by quoting Foucault's idea of a "body branded by history" and concludes that the "shock scenes" allow Yan Lianke to rewrite the historical narrative, although he views his style as a critical continuation of the revolutionary legacy (he compares Yan's reinvention of realism to Hu Feng's). ${ }^{(49)}$

Sun Yu's scholarly article, dated October 2011 and probably originally presented in one of the conferences held at People's University to raise awareness about the book, was published by a small Beijing publisher (Dolphin Books/Haitun) jointly with Zhongguo Guoji Chuban Jituan (CIPG) in a book of essays in May 2013. Sun describes the book as a "metaphysical fable," underlining its strangeness, achieved by "zero causality realism" and the use of four conflicting narratives of the same events. ${ }^{(50)}$ While he identifies "guilt" (zuigan 罪感) as the main theme, and takes care to point that this is not a "Confucian style" guilt, he does not spell out its origin.

The "silent rebellion" contained in both the character Religion and the author's afterword to the private edition, which provides Sun Yu with the title of his own essay collection ("Xiezuo de pantu"), is associated with a struggle against the "old" language, ${ }^{(51)}$ which readers can easily associate with the ideological tint of modern Chinese, especially when it is connected to the "quasi-religious mystical experience" in "times of fanaticism" (kuangre de shihou 狂熱的時候). Sun Yu describes Yan's linguistic "self-awareness" (zijue 自覺) of his own dependency on Mao style (Mao ti 毛體) as the greatest discovery of the book. In fact, we may surmise that Yan's elaborate structure, using four different narrative voices, is also a way of breaking up the unity of the Mao style, which he has previously both parodied (Serve the People) and tried to undermine by using dialect (Shouhuo). ${ }^{(52)}$

While they all highlight different aspects of the novel and discuss the historical events more or less explicitly, the fact that these three well-known scholars all published detailed discussions of a book that was not published in China shows how it can nonetheless enter the limited domestic public sphere.

\section{Polyphonic structure and fictional reception}

Although the polyphonic structure of the novel has already been noted, it is worth highlighting, in connection with its reception, that each of the "books" is provided with a distinct (fictional) publication and reception history in the introduction to the final chapter (p. 374). "Records of Criminals" is the first to have been purportedly published, as an internal Party document in the 1980s. It is the least threatening to the government, echoing the autobiographical and self-righteous personal bias of the intellectuals involved in the Scar literature movement. "The Old Course" is said to have been published in 2002 with little reverberation: readers are no longer interested in such old stories. "The Child of Heaven" is an anonymous volume that the narrator has allegedly found in an old second-hand store, from a pub- lisher specialising in myths and legends. Yan Lianke has thus inscribed within his own novel the nascent public sphere in which history can be discussed and in which various types of "interventions" may take place, mirroring the opening up of a sphere of discussion that he hopes to provoke in reality.

The fourth "book," the "New Myth of Sisyphus," raises several questions in its own right. Alone among the four books, it is not a narrative; we are only given to read the preface of a longer but unfinished manuscript described as "obscure and incomprehensible" (huise nandong 晦澀難懂), which the narrator has purportedly consulted in a research archive. It is ostensibly authored by the Scholar, the only one of the inmates to refuse to undergo reform through labour, and it is also the manuscript that the Child is to take to Beijing, which explains how it may have ended up in an archive. The "preface" consists of a rewriting of the myth of Sisyphus, in which the gods punish Sisyphus, who has gotten used to rolling his stone up the hill (and meeting a mysterious child on the way), by making his stone roll up the hill by itself - like a cart carrying the red star made of steel in one of the episodes of "The Child of Heaven" (chapter 9) - and forcing him to roll it down. Like the famous writers of the 1980s, Yan Lianke remains indebted to a form of cultural critique of Chinese civilisation (perhaps also implicit in the idea of the "Old Course" of the Yellow River): while Western intellectuals role their stone upwards and strive for an ideal, Chinese intellectuals roll their stone downwards in search of more concrete advantages in the present world: food, riches, health, a large and prosperous family. ${ }^{(53)}$ While the Western Sisyphus, accepting his punishment, is guilty of developing feelings for the child, the Eastern Sisyphus, when he adapts to pushing the rock downwards, "feels affection for the smoke and the temple" that stand for the human world at the bottom of the mountain. "The smoke of reality has given Sisyphus a new meaning in the midst of his punishment, the force to adapt" (p. 380). Sun Yu reads this final revelation as a farewell to the illusions of transcendence, whether religious or political, and the acceptance of reality as the ultimate choice of reason: "On the one hand, Chinese people have no metaphysical life, but at times of fanaticism, they have gone through a mystical experience comparable to religion. Yan Lianke's interest is in resisting both of these modes of existence." (54)

\section{Conflicting narratives of history}

With its title alluding both to the canonical texts of Confucianism (Four Books and Five Classics) and Lu Xun's indictment of the "cannibalism" they contain, and to the four Gospels - four different accounts of a similar series

48. Ibid., p. 22

49. Chen Xiaoming, "'Zhenjing' yu lishi chuangshang de qiangdu. Yan Lianke xiaoshuo xushi fangfa tantao." "Shock" and the strength of historical trauma:A discussion of narrative technique in Yan Lianke's fiction), Dangdai Zuojia pinglun (Review of Contemporary Writers), Vol. 2013/5, 2013, pp. 22-30 (special issue on Yan Lianke). The question of realism is of course contentious. Yan Lianke defines his own style as "mythical realism" (shen shi zhuyi), a form of writing that unearths the unreal within reality, notably by reconfiguring causal relations. Yan Lianke, Faxian xiaoshuo, Taipei, INK, 2011, especially the last section pp. 172-200.

50. Sun Yu, "Xiezuo de pantu" in Xiezuo de pantu (The Writer as Rebel), Beijing, Haitun, 2012, p. 127. "Zero causality" is a concept developed by Yan Lianke in Faxian xiaoshuo, op. cit.

51. "Zuozhe buduande zhengtuo jiu de yuyan xiguan gei ziji dailai de yapo" (The writer is continually struggling against the pressure he experiences from the old language) in Sun Yu, Xiezuo de pantu, op. cit., p. 134.

52. See Tsai Chien-hsin's discussion in "In Sickness or in Health:Yan Lianke and the writing of auto-immunity," Modern Chinese Literature and Culture, Vol. 23/1, 2011, pp. 77-104, especially pp. 93-94.

53. Interview with Yan 2013: Yan sums up this opposition as jinsheng (present life) vs. houshi (the next world).

54. Sun Yu, "Xiezuo de pantu," art. cit., p. 137 
of events - the book immediately raises the question of conflicting orthodox or heterodox - narratives of Chinese history. In the New York Times article, Yan criticises the logic of official writing as a dampening of the critical mind: "Gradually we become accustomed to amnesia and we question people who ask questions." In Four Books, by contrast, the tension between the four accounts throws up questions that cannot be easily dismissed. Of the four books, three are narratives and one is a discursive essay; two refer to canonical intertexts - the Bible and the myth of Sisyphus - while two others are a factual and a fictional version of the same events, ostensibly authored by the Writer. The title of the Writer's novel is Gudao ("The Old Course"), which refers to the old course of the Yellow River. Yan glosses this as an alternative course of history, and as such, as a trope for fiction, as opposed to the documentary writing in the "Records of Criminals" (Zuirenlu): in one case, Yan argues, everything is true, and the inmates' crimes have been faithfully noted. In the other, the novel Gudao, the account may be fictionalised, in particular the episode of self-cannibalism, but it may well be truer than the informer's reports in that it represents the Writer's sincere self-reflection. ${ }^{(55)}$ As Yan puts it, the reality of feeling attracts more readers than historical investigation, because it allows an "individual judgment" (geren de panduan) and starts out from the point of view of the individual. (56) The same story can therefore be told as a "gospel" - a tenet of faith that cannot be questioned, or as a series of informant's reports, or as fiction. Each of these narratives raises ethical questions about the status and stance of the narrator or alleged writer, and about the connection between the account and the historical events that serve as its point of reference. More important than re-establishing the "truth" - which fiction is in any case illequipped to do - Yan therefore succeeds in opening up a space for discussion, using both narrative (conflicting stories) and linguistic (parody of different styles including Mao ti) polyphony.

Hence, while circumscribing his essay to an ostensibly aesthetic discussion, Sun Yu makes clear that his interest in the book is motivated by the re-examination of "twentieth century history" that it undertakes: "Four Books seems to be parodying history, but in fact, this struggle is a way of dealing with a cognitive void." (57) This readily accessible article deals directly with the major issues of the novel and the historical period, and points interested readers straight to the original work itself, which they may then read in pirated versions on the internet or purchase in Hong Kong.

\section{Conclusion}

This brief outline of the novel's reception attests to the growing complexity of the Chinese public sphere. The issue is no longer so much whether a book is censored or published within China - after all, even books that were published can go out of print, and publishers can be strategically prevented from reprinting them - but rather whether and in what terms it is publicly discussed, in academic venues, on the internet, in privately owned bookstores or cafes. In the case of Yan's novel, the academic, journalistic, and critical reception achieved by Four Books is sufficient to bring about a form of public discussion.

Yan Lianke has taken pains to substantially transform the mainstream literary narrative of the Mao era, while leaving his text as open as possible. One of his narratives represents an indictment of Maoism as blind faith; however it is only one of four narratives. In order to achieve openness, Yan leaves the relationship between the four "books" that make up his novel ambiguous, and leaves it to the readers to draw their own conclusions as to how to reconcile the biblical profession of faith, the historical material, the fictional epic, and finally the philosophical reflection. As Sun Yu writes, this is a way of leaving a "void" (kongbai 空白) at the centre of the novel. While the novel was ultimately not published in China, it was published in both Hong Kong and Taiwan and circulated in pirated editions and on the Chinese Internet. It was also discussed in various publications and academic conferences or other venues. In this sense, it represents a further contribution to the growing pool of interventions that actively call into question the official narrative of history of the Mao era within China.

\section{Sebastian Veg is researcher and director of the CEFC.}

CEFC, 20/F Wanchai Central Building, 89 Lockhart Road, Wanchai, Hong Kong (sveg@cefc.com.hk). 